\title{
Curriculum Management During the Covid-19 Emergency
}

\author{
Putri Dwi Arini1*, Matin², Siti Zulaikha ${ }^{3}$ \\ 1,2,3 Post-graduate Program State University of Jakarta, Jakarta, Indonesia
}

\section{A R T I C L E IN F O}

Article history:

Received January 28, 2021

Revised February 10, 2021

Accepted April 24, 2021

Available online May 25, 2021

Kata Kunci :

Manajemen, Kurikulum,

Pembelajaran JarakJauh

Keywords:

Management, Curriculum,

Distance Learning

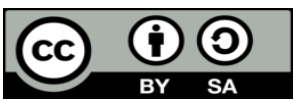

This is an open access article under the CC BY-SA license.

Copyright $(2021$ by Author. Published by Universitas Pendidikan Ganesha

\begin{abstract}
A B S T R A K
Penyebaran wabah Covid-19 yang melanda dunia mengakibatkan banyak negara menutup kegiatan belajar mengajar baik di sekolah maupun lembaga pendidikan lainnya. Pengelolaan kurikulum yang berjalan pada masa darurat Covid-19 sangat menarik untuk ditelaah, apalagi masih sedikit penelitian yang membahas tentang pengelolaan kurikulum pada kondisi khusus. Penelitian ini diharapkan dapat memberikan informasi tentang bagaimana manajemen kurikulum darurat bekerja melawan pandemi global. Penelitian ini bertujuan untuk menganalisis kegiatan pembelajaran jarak jauh melalui manajemen kurikulum pada masa darurat Covid-19. Metode penelitian menggunakan pendekatan kualitatif deskriptif dan subjek penelitian adalah kepala sekolah, guru, dan beberapa siswa yang diambil berdasarkan pengangkatan. Teknik pengumpulan data melalui observasi, wawancara dan dokumentasi. Hasil kajian menunjukkan bahwa sistem manajemen kurikulum pada masa darurat Covid-19 sudah berjalan sebagaimana mestinya, perencanaan kurikulum yang melibatkan pejabat daerah dan pihak sekolah, pengorganisasian dengan mensosialisasikan program kurikulum kepada seluruh guru, pelaksanaan pembelajaran online terkendala karena sekolah kondisi dan keterbatasan teknologi yang dimiliki siswa dan hal ini menjadi faktor yang membuat pembelajaran online tidak efektif dilaksanakan, dan evaluasi kurikulum berdasarkan masukan dari pihak sekolah dan tidak melibatkan siswa dan orang tua siswa.
\end{abstract}

\begin{abstract}
A B S T R A C T
The spread of the Covid-19 outbreak that hit the world has resulted in many countries closing teaching and learning activities both in schools and other educational institutions. The management of the curriculum which was running during the Covid-19 emergency is very interesting to examine, especially there is still little research that discusses curriculum management during special conditions. This research is expected to provide information on how emergency curriculum management works against the global pandemic. This study aims to analyze distance learning activities through curriculum management for the Covid-19 emergency period. The research method used a descriptive qualitative approach and the research subjects were the principal, teachers, and several students who were taken based on the appointment. Data collection techniques through observation, interviews and documentation. The findings from the study show that the curriculum management system during the Covid-19 emergency has been running as it should, curriculum planning involving local officials and school authorities, organizing by disseminating curriculum programs to all teachers, implementing online learning is constrained due to school conditions and limited technology owned by students and this is a factor that makes online learning not effectively implemented, and curriculum evaluation is based on input from the school and does not involve students and parents of students.
\end{abstract}

\section{INTRODUCTION}

The spread of the Covid 19 outbreak that hit the world has resulted in many countries closing teaching and learning activities both in schools and other educational institutions. UNESCO, the United Nations Educational, Scientific and Cultural Organization stated that there are at least 290.5 million students worldwide whose learning activities are disrupted due to the closure of schools (Chaturvedi et al., 2021; Purwanto et al., 2020). As an effort so that students can still participate in learning activities, many countries organize distance learning (Basilaia \& Kvavadze, 2020; Goldschmidt, 2020). Indonesia, which was also affected by the Covid 19 pandemic, has also organized distance learning or learning from home. This policy is in accordance with the Circular of the Ministry of Education and Culture (Kemendikbud) No. 4 of 2020 concerning the implementation of education in the Covid-19 emergency period (Anugrahana, 2020), which is strengthened by Circular No.15 of 2020 concerning guidelines for organizing learning from home in the emergency period of the spread of Covid-19 (Agung \& Surtikanti, 2020; Santika, 2020). 
The distance learning system (PJJ) can be done by learning in the internet network (online) such as using the zoom application, google class room (Napitupulu, 2020), outside the internet network (offline) such as teachers visiting students at home, learning using television media, or students send assignments physically directly to their teachers (Ambarita et al., 2020), or with a combination of both (Suhendro, 2020). The PJJ approach can be selected or adjusted to the characteristics of the lesson and the availability of teaching materials, as well as the readiness of school facilities and infrastructure and students (Ali et al., 2020). The implementation of distance learning presents several challenges and obstacles experienced by students and teachers, one of which is the reduced learning hours. Previously, learning activities could be done twice 45 minutes, when PJJ was only done once 45 minutes (Firmansyah \& Kardina, 2020). This certainly has an impact in meeting the targets of the ongoing curriculum, because the implementation of PJJ that is running does not pursue curriculum completeness, but emphasizes literacy and numeracy competencies (Asmuni, 2020).

The government itself is aware of the obstacles and challenges faced by teachers and students, therefore the government has designed a special curriculum or emergency curriculum that can be used during the Covid 19 pandemic. The emergency curriculum itself is designed simply to facilitate long distance learning (PJJ) and ease the burden on teachers, people. parents / guardians and students during the pandemic (Sanjaya \& Rastini., 2020). In addition to the emergence of an emergency curriculum, the Government also provides flexibility for educational units in choosing a curriculum that suits learning needs. Through the Decree of the Minister of Education and Culture of the Republic of Indonesia Number 719/P/2020 concerning Guidelines for Implementing Curriculum in Education Units in Special Conditions, the Government has given freedom for the education unit to be able to use one of the three curricula, namely the National Curriculum, the emergency curriculum or carry out curriculum simplification independently which adapted to learning needs (Istaryatiningtias et al., 2021).

The freedom given in choosing the curriculum has a positive meaning for each school. This is because during the Covid 19 pandemic, each school faced different conditions and needs. The differences faced by each school allow for differences in choosing and planning curriculum, implementing learning activities and assessing learning outcomes (Daniel, 2020; Jusuf \& Maaku, 2020). Likewise, SMAN 1 Baturetno Wonogiri which was based on the emergency condition of SMAN 1 Baturetno Wonogiri, which simplified the curriculum independently according to learning needs. The curriculum implemented by SMAN 1 Baturetno Wonogiri has implemented curriculum management which includes curriculum planning, curriculum organization, curriculum implementation, and curriculum evaluation (Fathurrochman, 2017).

The management of the curriculum at SMAN 1 Baturetno Wonogiri which was running during the Covid 19 emergency is very interesting to examine, especially there is still little research that discusses curriculum management during special conditions. This research is expected to provide information on how emergency curriculum management works against the global pandemic. This research is also a reference for further research related to learning management in the era of the global pandemic, can add insight and experience to the structure of learning management, especially those that occur during emergencies like today. Educators, education staff, and schools can increase their knowledge in order to develop teaching skills both online and non-online. Likewise, schools can arrange learning programs with appropriate methods to develop student potential.

\section{METHODS}

This research uses descriptive qualitative approach. There are two sources of data in this study, namely primary data and secondary data. Primary data is a source of data derived from interviews conducted with respondents, namely: 1) Principal as key informant, 2) Teachers as supporting informants I, 3) Students as supporting informants II, and 4) Parents committee as supporting informants III. Meanwhile, secondary data is documentation related to emergency curriculum management. The documents relevant to this research include: daily activity schedules, academic calendars, school profiles, data of all teachers and school education personnel, data on vision, mission and school goals, school organizational structure, and teacher administration (Yearly and Semester Programs, Syllabus and lesson plan), and teacher evaluation reports during PJJ in the form of supervision results and survey results for filling out a google forms questionnaire from students. This study uses a qualitative descriptive approach with the data analysis model of Miles and Huberman (Milles \& Huberman, 1992; Sugiyono, 2014), where activities in data analysis, both data reduction, data presentation, and conclusion drawing are carried out interactively and continuously. as for the interactive model in data analysis as shown in Figure 1. 


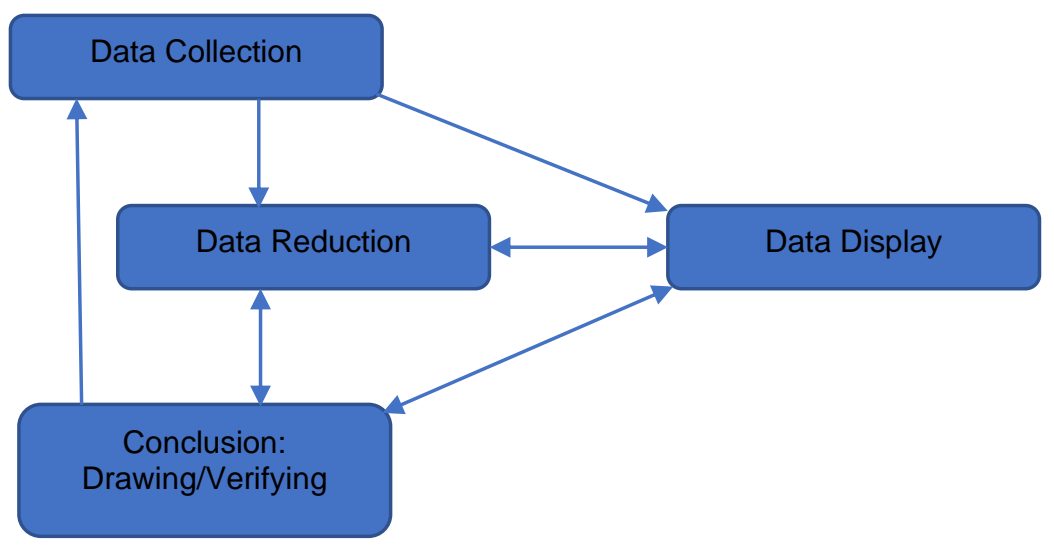

Figure 1. Interactive Model of Qualitative Data Analysis (Milles \& Huberman, 1992)

Likewise, the validity of the data, namely the degree of trust (credibility), transferability (transferability), dependability (dependability) and the certainty of data and research results (confirmability) (Moleong, 2012). The explanation of management component in this study is presented in Table 1.

Table 1. Design of Research of Learning Management

\section{Management} Components

Learning Planning

Organizing Learning

Implementation of Learning

Remote Learning Monitoring

\section{Explanation}

Systematic learning

arrangement with a series of learning activities with various techniques that can be developed to suit the objectives to be achieved

The process of preparing an organizational structure in accordance with the objectives, resources, and environment included in it, including division of tasks, delegation, division of authority, and coordination between divisions so that their function is visible in the implementation of activities

The efforts made by a group (for example: teachers to students) in order to achieve a goal based on a pre-designed plan

Systematic efforts are made so that the implementation of

\section{Indicator}

a) Applications used

b) Making a syllabus

c) RPP model and schedule (Learning Implementation Plan)

d) Teaching materials used (summary, worksheets, PowerPoint)

e) Method and media used (youtube, video)

f) Learning assessment plan

g) Learning participants

h) Learning support facilities

a) Curriculum coordinator

b) Person in charge of IT

c) Teaching material coordinator

d) Media coordinator

e) Create online course schedules

f) Compile a list of principal meetings with teachers

g) Compile a list of teacher meetings with teachers

h) Share assignments among subject teachers online

a) The role of the principal in coordination with teachers on virtual lesson plans

b) The role of the teacher in online teaching routines

c) The role of parents in assisting children to learn online if someone does not understand

d) The role of students to listen and understand what the teacher says

a) Monitoring is done with Whatsapp group, Youtube, Email, Google classroom 


\begin{tabular}{lll}
\hline $\begin{array}{l}\text { Management } \\
\text { Components }\end{array}$ & \multicolumn{1}{c}{ Explanation } & \multicolumn{1}{c}{ Indicator } \\
\hline & $\begin{array}{l}\text { distance learning starting } \\
\text { from planning, organizing, }\end{array}$ & $\begin{array}{l}\text { b) Giving assignments to students and then } \\
\text { collected through google classroom giving } \\
\text { and implementing runs } \\
\text { oral and written test subjects to students and } \\
\text { collected via WhatsApp (the test aims to } \\
\text { make online teaching truly understood by } \\
\text { mission is achieved }\end{array}$ \\
\hline
\end{tabular}

\section{RESULT AND DISCUSSION}

\section{Results}

According to the school's official website at http://sman1baturetno.sch.id/, currently SMAN 1 Baturetno has opened 33 classes, namely class X, XI, XII MIPA, each of which has 6 (six) classes and class X, XI, XII IPS there are 5 (five) classes each. With a total of 1,176 students from the 2019/2020 class. There are 1 (one) Principal, 72 (seventy-two) teachers, and 28 employees. The location of SMAN 1 Baturetno is in a mountainous area, and almost $25 \%$ of students' experience signal difficulties and a minimum quota, so the private school makes a policy that once-a-week students are required to go to school to collect assignments, this is done to make it easier for students to follow online learning (for those with signal difficulties) and control all students, so that cheating does not occur. As for the activities carried out by students through Distance Learning (PJJ), namely, learning material concepts, participating in discussion forums, compiling works that are relevant to the material, and following assessments designed by the teacher to determine student learning outcomes. Monitoring the success of PJJ is carried out in 2 (two) ways, namely: (1) The teacher monitors the activeness of students in PJJ (Distance Learning), (2) makes an assessment of the learning development of their students. Regarding, the assessment, PJ) at SMAN 1 Baturetno was conducted semi online. There are several assignment activities that are billed online and there are also products (works) of students that are submitted to schools directly by taking turns and still paying attention to health protocols. This is solely done to oversee the PJJ (Distance Learning) process so that it is right on target and running as it should.

\section{Learning Planning for the Covid-19 Pandemic}

Planning carried out by schools has intersected with the increasing outbreak of COVID-19 since March 2020, therefore the central government has mandated all schools in Indonesia, both public and private, to carry out learning at home. The Principal of SMAN 1 Baturetno held a closed meeting assisted by the Deputy Principal of the Curriculum section to realize the implementation of Distance Learning (PJJ) according to the direction of the Government so that it could be implemented at SMAN 1 Baturetno. The Deputy Principal of the Curriculum section creates a new teaching schedule for all teachers, which is usually 3-6 hours per week in each subject, now for online teaching schedules only 1 hour is given per week for all subjects, with Basic Competencies (The streamlined KD) also has the effect of changing all teaching materials that have been prepared by the teacher beforehand, to follow the latest directions from the school.

\section{Organizing Learning during the Covid-19 Pandemic}

After a curriculum change had an impact on changes in the Teaching and Learning Activities (KBM) which initially studied face-to-face then changed to distance learning, then a SK (Certificate) was dropped from the Principal, then the Deputy Head of the Curriculum made a separate schedule regarding online learning, of course with basic competencies and shortened time. The program that has been designed is then socialized to teachers through webinars. In addition to conveying Distance Learning (PJJ) mechanisms / techniques, teachers are also trained to operate applications that allow them to be used as a medium for delivering Distance Learning (PJJ), such as Google Classroom, Quiziz, and Microsoft Teams.

\section{Learning Implementation during the Covid-19 Pandemic}

The implementation of PJJ at SMA Baturetno has problems, namely limited signal due to the location of the school which is in the middle of the mountains and is located in a remote area, so that the school, both the Principal, Deputy Principal of the Curriculum section, Subject Teachers, and other staff must be smart in respond to these natural conditions. In the end, SMAN 1 Baturetno decided to carry out semi-online learning. This step was taken because many students had difficulty learning in full online (zoom or google meetings). Teachers often find students unable to take part in online learning. Many 
factors influence it, including the cellphones used by students who are still one with their parents, so that students are not free to always update the assignments given by the teacher, then when students are able to buy personal cellphones, the location of their house is on the same mountain. completely out of reach of the signal. There are many things to strengthen the school that SMAN 1 Baturetno will not be able to undergo full online learning like schools in cities that are easy to get signals and sufficient quota. There is a lot of leeway and acknowledgment made by the school so that all students can participate in the learning as much as possible. In fact, it can be said that teachers who follow the wishes of students, if they cannot be collected at school, are allowed to collect them via personal WhatsApp, because there are some students who are still reluctant to leave the house and use public transportation. During PJJ, schools find it difficult to achieve effective learning. Likewise, student discipline has decreased, many rules have been violated because of the loss of teacher interaction in terms of character education.

\section{Learning Evaluation during the Covid-19 Pandemic}

According to the statement of the provincial office representative who handles supervision at SMAN 1 Baturetno, it is allowed to go to school once a week just to collect assignments, of course by still paying attention to health protocols, not in school uniform, and scheduling each class, so there is no clash, and of course no learning is held in the classroom. If there are schools that secretly learn in class with many students, even though they are not in uniform, the school will be sanctioned by the local office. With the enactment of the emergency curriculum, starting from learning planning, organizing learning, and implementing learning, there is a need for evaluation to find out whether the learning management system in this pandemic era is as expected. Therefore, on Tuesday, 27 October 2020, a 2020 Distance Learning Evaluation (PJJ) meeting was held at SMAN 1 Baturetno. In the meeting discussed 5 (five) main topics, namely Distance Learning Evaluation (PJJ), Principal Performance Assessment (PKKS), Supervision, Learning Implementation Plan during Distance Learning (RPP PJJ), and Teacher Performance Assessment (PKG) leading to List of Proposed Credit Figures (DUPAK). In addition to the PJJ evaluation survey data above, the principal also conducts teacher supervision.

\section{Discussion}

Based on the results of the research that has been done, SMAN 1 Baturetno is well prepared for the emergency situation of COVID-19. The freedom in choosing the curriculum has been put to good use by the school management of SMAN 1 Baturetno, namely by selecting and developing learning materials that are specialized in the pandemic period by considering the development of science and technology possessed by students (Nasbi, 2017). The freedom of SMAN 1 Baturetno in choosing the curriculum is in line with opinion that the 2013 Curriculum was not formulated to deal with a pandemic (Wahyono et al., 2020), therefore it requires a flexible curriculum and flexibility for schools and teachers in choosing learning materials. Of course, the freedom of material selection is carried out without reducing the quality of learning so that educational activities can continue (Daniel, 2020). Freedom in choosing a curriculum needs to be balanced with a good curriculum management system and support from the authorities, students and parents of students so that the implementation of the curriculum during the Covid 19 emergency can be directed and in accordance with the objectives to be achieved (Nóvoa \& Alvim, 2020; Rasmitadila et al., 2020; Utami et al., 2019).

The curriculum management system in emergency situations that is run by SMAN 1 Baturetno itself has been running well, starting with the curriculum planning stage by involving local education officials and school officials such as the Deputy Principal of the Curriculum Sector. The involvement of the parties referred to in curriculum planning is very important, this is related to determining the objectives of who will receive the program, learning time, learning materials and methods adapted to the conditions of the community during the pandemic (Kihc, 2015; Saajidah, 2018; Taha et al., 2020). At the stage of organizing the curriculum, SMAN 1 Baturetno socialized the emergency condition curriculum to all teachers. In addition to conveying material changes and the duration of learning time, the school also conveyed the Distance Learning mechanism to be used. Organizing the emergency curriculum for all teachers is very important, because organizing the curriculum plays an important role in achieving learning goals effectively and efficiently (Sesanti et al., 2020). With the organization, it is hoped that the teacher can understand and carry out their duties and responsibilities properly so that the objectives of the emergency curriculum can be achieved.

At the stage of implementing the emergency curriculum, SMAN 1 Baturetno has realized that the online PJJ method cannot be fulfilled in full. Limited communication signals due to the location of the school being in remote areas and in the mountains and the limited equipment owned by students are obstacles to the full implementation of online PJJ. As with previous studies, the limitations of signals and devices have resulted in students being late in learning, late submitting assignments, and decreased 
student discipline by being absent from learning activities (Putri et al., 2020; Setyorini., 2020). Overcoming existing problems, the teacher is forced to come to the student's house not to provide offline learning, but more to find out the student's condition. This shows that in planning the curriculum for emergency conditions at SMAN 1 Baturetno, it does not consider the use of an offline system in the implementation of PJJ. In fact, one way to overcome the obstacles of online PJJ is to use PJJ offline (Ambarita et al., 2020). The results show that the implementation of offline PJJ can be done by the teacher visiting or creating study groups of students who have online PJJ problems, then explaining the learning material and giving assignments with modules that have been prepared from the school (Manuputy \& Lakoruhut, 2020; Mokodompit, 2020). Of course, offline PJJ activities can be carried out by following government regulations and health protocols to prevent the spread of Covid-19 (Munajim et al., 2020).

The last stage of curriculum management is evaluating. Curriculum management evaluation aims to improve curriculum subsidence, curriculum implementation procedures, instructional methods, and their effects on student learning and behavior (Adnan, 2017). Moreover, during the Covid 19 pandemic, freedom in choosing and compiling curriculum materials required the role of educators to evaluate whether the implementation of PJJ was running effectively and in accordance with student learning needs (Herliandry et al., 2020). As with the curriculum evaluation conducted by SMAN 1 Baturetno, school educators evaluate the implementation of Distance Learning (PJJ), Learning Implementation Plans during Distance Learning (RPP PJJ), and the development of student behavior while participating in PJJ. During the evaluation, SMAN Negeri 1 Baturetno did not involve students. Even though evaluations that come from student feedback are very important as input and an instrument for improvement in curriculum implementation (Sudrajat et al., 2020).

\section{CONCLUSION}

Based on the description that has been conveyed, it can be concluded that during the Covid 19 emergency, the learning process can still be carried out by many educational institutions. With government support, educational institutions and students can carry out distance learning activities both with an online, offline approach and by combining online and offline. In addition, the freedom given by the government in choosing a curriculum helps many educational institutions and students in selecting and determining curriculum materials in accordance with the development of science and technology that is owned by society. Even in the emergency period of Covid 19, the implementation of the curriculum can run according to its objectives if it is supported by a good curriculum management system. As for the suggestions that can be given, the need for SMAN 1 Baturetno to implement Distance Learning with an offline approach. Besides being able to help students with problems in online PJJ, offline PJJ can help students to better understand learning materials obtained from learning practices carried out together. In addition, schools need to communicate with students and parents to ask for feedback on the implementation of the curriculum, this needs to be done because complaints and obstacles experienced by students and parents can be very positive input to improve and improve the quality of learning.

\section{REFERENCES}

Adnan, M. (2017). Evaluasi Kurikulum Sebagai Kerangka Acuan Pengembangan Pendidikan Islam. AlIdaroh: Jurnal Studi Manajemen Pendidikan Islam, 1(2), 108-129. https://jurnal.stituwjombang.ac.id/index.php/al-idaroh/article/view/25.

Agung, A. S. N., \& Surtikanti, M. W. (2020). Students' Perception of Online Learning during COVID-19 Pandemic: A Case Study on the English Students of STKIP Pamane Talino. SOSHUM : Jurnal Sosial Dan Humaniora, 10(2), 225-235. https://doi.org/10.31940/soshum.v10i2.1316.

Ali, M., Prawening, C., \& Samiaji, M. H. (2020). Inovasi Model Pembelajaran Jarak Jauh Program Kesetaraan Paket C Di Masa Pandemi Covid-19. JIV-Jurnal Ilmiah Visi, 15(2), 107-116. https://doi.org/10.21009/jiv.1502.2.

Ambarita, J., Jarwati, \& Restanti, D. K. (2020). Pembelajaran Luring (Abdul (ed.)). CV. Adanu Abimata.

Anugrahana, A. (2020). Hambatan, Solusi dan Harapan: Pembelajaran Daring Selama Masa Pandemi Covid-19 Oleh Guru Sekolah Dasar. Scholaria: Jurnal Pendidikan Dan Kebudayaan, 10(3), 282-289. https: //doi.org/10.24246/j.js.2020.v10.i3.p282-289.

Asmuni. (2020). Problematika Pembelajaran Daring di Masa Pandemi Covid-19 dan Solusi Pemecahannya. Jurnal Paedagogy, 7(4), 281-288. https://doi.org/10.33394/jp.v7i4.2941.

Basilaia, G., \& Kvavadze, D. (2020). Transition to Online Education in Schools during a SARS-CoV-2 Coronavirus (COVID-19) Pandemic in Georgia. Pedagogical Research, 5(4). 
https: //doi.org/10.29333/pr/7937.

Chaturvedi, K., Vishwakarma, D. K., \& Singh, N. (2021). COVID-19 and its impact on education, social life and mental health of students: A survey. Children and Youth Services Review, 121. https://doi.org/10.1016/j.childyouth.2020.105866.

Daniel, S. J. (2020). Education and the COVID-19 pandemic. Prospects, 49(1-2), 91-96. https://doi.org/10.1007/s11125-020-09464-3.

Fathurrochman, I. (2017). Implementasi Manajemen Kurikulum Dalam Upaya Meningkatkan Mutu Santri Pondok Pesantren Hidayatullah/Panti Asuhan Anak Soleh Curup. Tadbir : Jurnal Studi Manajemen Pendidikan, 1(1), 85. https://doi.org/10.29240/jsmp.v1i1.216.

Firmansyah, Y., \& Kardina, F. (2020). Pengaruh New Normal Ditengah Pandemi Covid-19 Terhadap Pengelolahan Sekolah Dan Peserta Didik. Jurnal Buana Ilmu, 4(2), 99-112. https://doi.org/10.36805/bi.v4i2.1107.

Goldschmidt, K. (2020). The COVID-19 Pandemic: Technology use to Support the Wellbeing of Children. $\begin{array}{lllll}\text { Journal of } & \text { Pediatric } & \text { Nursing, }\end{array}$ https: //www.ncbi.nlm.nih.gov/pmc/articles/pmc7161478/.

Herliandry, L. D., Nurhasanah, N., Suban, M. E., \& Kuswanto, H. (2020). Pembelajaran Pada Masa Pandemi Covid-19. JTP - Jurnal Teknologi Pendidikan, 22(1), 65-70. https://doi.org/10.21009/jtp.v22i1.15286.

Istaryatiningtias, Bahri, F. Y., Najmudin, \& Hidayat, E. (2021). Implementasi Demokratisasi Kurikulum Pada Masa Pandemi Covid-19. Jurnal Syntax Transformation, 2(1), 93-104.

Jusuf, R., \& Maaku, A. (2020). Kurikulum Darurat Covid 19 di Kota Kotamobagu; Fenomena dan Realita Guru Madrasah. Jurnal Ilmiah Iqra', 14(2), 155. https://doi.org/10.30984/jii.v14i2.1188.

Kıhc, F. (2015). The Future of Curriculum Development in Distance Education. In Curriculum design and classroom management: Concepts, methodologies, tools, and applications. IGI Global. https: //doi.org/10.1007/978-1-466-68247-4.

Manuputy, P., \& Lakoruhut, N. (2020). Problematika Guru Pendidikan Agama Kristen Dalam Pembelajaran $\begin{array}{lllll}\text { Pada Masa } & \text { Pandemi } \quad \text { Covid-19. } & \text { DIDAXEI, } & \text { http:/e- }\end{array}$ journal.iaknambon.ac.id/index.php/DX/article/view/220.

Milles, M. B., \& Huberman, A. M. (1992). Analisis Data Kualitatif (T. R. Rohidi \& Mulyarto (eds.)). Universitas Indonesia Press.

Mokodompit, I. S. (2020). Home Visit sebagai Refleksi Kurikulum Darurat Covid-19: Kesiapan Guru, Respon Siswa, Materi dan Hasil Belajar di Madrasah Tsanawiyah. Jurnal Manajemen Dan $\begin{array}{ll}\text { Pendidikan } \quad \text { Islam, } & \text { 6(2), }\end{array}$

119-131. https: //mail.journal.unipdu.ac.id/index.php/dirasat/article/download/2200/1155.

Moleong, L. J. (2012). Metodologi Penelitian Kualitatif. Remaja Rosdakarya.

Munajim, A., Barnawi, \& Fikriyah. (2020). Pengembangan Kurikulum Pembelajaran di Masa Darurat. CENDEKIA: Jurnal Riset Pedagogik, 4(1), 114-124. https://doi.org/10.20961/jdc.v4i2.45288.

Napitupulu, R. M. (2020). Dampak pandemi Covid-19 terhadap kepuasan pembelajaran jarak jauh. Jurnal Inovasi Teknologi Pendidikan, 7(1), 23-33. https://doi.org/10.21831/jitp.v7i1.32771.

Nasbi, I. (2017). Manajemen Kurikulum: Sebuah Kajian Teoritis. Idaarah: Jurnal Manajemen Pendidikan, 1(2), 318-330. https://doi.org/10.24252/idaarah.v1i2.4274.

Nóvoa, A., \& Alvim, Y. (2020). Nothing is new, but everything has changed: A viewpoint on the future school. Prospects, 40(1-2), 35-41. https://doi.org/10.1007/s11125-020-09487-w.

Purwanto, A., Pramono, R., Asbari, M., Santoso, P. B., Wijayanti, L. M., Choi, C. H., \& Putri, R. S. (2020). Studi Eksploratif Dampak Pandemi COVID-19 Terhadap Proses Pembelajaran Online di Sekolah Dasar. EduPsyCouns: Journal of Education, Psychology and Counseling, 2(1), 1-12. https://ummaspul.ejournal.id/Edupsycouns/article/view/397.

Putri, R. S., Purwanto, A., Pramono, R., Asbari, M., Wijayanti, L. M., \& Hyun, C. C. (2020). Impact of the COVID-19 pandemic on online home learning: An explorative study of primary schools in Indonesia. International Journal of Advanced Science and Technology, 29(5), 4809-4818. https: //search.bvsalud.org/global-literature-on-novel-coronavirus-2019ncov/resource/en/covidwho-830197.

Rasmitadila, Aliyyah, R. R., Rachmadtullah, R., Samsudin, A., Syaodih, E., Nurtanto, M., \& Tambunan, A. R. S. (2020). The perceptions of primary school teachers of online learning during the covid-19 pandemic period: A case study in Indonesia. Journal of Ethnic and Cultural Studies, 7(2), 90-109. https://doi.org/10.29333/ejecs/388.

Saajidah, L. (2018). Fungsi-Fungsi Manajemen Dalam Pengelolaan Kurikulum. Jurnal Islamic Education Manajemen, 3(2), 201-208. https://doi.org/10.15575/isema.v3i2.5012.

Sanjaya, J. B., \& Rastini. (2020). Implementasi Kurikulum Darurat Di Masa Pandemi Covid-19 Dalam Upaya 
Pemenuhan Hak Pendidikan. Journal of Indonesian Law, 1(2), 161-174. https: //doi.org/10.31227/osf.io/qnzhb.

Santika, I. W. E. (2020). Pendidikan Karakter pada Pembelajaran Daring. Indonesian Values and Character Education Journal, 3(1), 8-19. https://doi.org/10.23887/ivcej.v3i1.27830.

Sesanti, A. H., Burhanuddin, \& Ulfatin, N. (2020). Persepsi Guru Dan Siswa Tentang Efektivitas Manajemen Kurikulum Dan Pengaruhnya Terhadap Kreativitas Siswa Sekolah Menengah Atas. JAMP: Jurnal Adminitrasi Dan Manajemen Pendidikan, $3(4), \quad$ 171-181. http://journal2.um.ac.id/index.php/jamp/article/view/13722.

Setyorini. (2020). Pandemi Covid-19 dan Online Learning: Apakah Berpengaruh Terhadap Proses Pembelajaran Pada Kurikulum 13? Journal of Industrial Engineering \& Management Research, 1(1). https://doi.org/10.7777/jiemar.v1i1.31.

Sudrajat, T., Komarudin, O., Ni'mawati, \& Zaqiah, Q. Y. (2020). Inovasi Kurikulum dan Pembelajaran Pada Masa Pandemi Civid-19. Jurnal Ilmiah Wahana Pendidikan, 6(3), 317-347. https://doi.org/10.5281/zenodo.3960178.

Sugiyono. (2014). Metode Penelitian Pendidikan Pendekatan Kuantitatif, Kualitatif, dan R\&D. Alfabeta.

Suhendro, E. (2020). Strategi Pembelajaran Pendidikan Anak Usia Dini di Masa Pandemi Covid-19. Jurnal Golden Age, 5(3), 133-140. https://doi.org/10.14421/jga.2020.53-05.

Taha, M. H., Abdalla, M. E., Wadi, M., \& Khalafalla, H. (2020). Curriculum delivery in Medical Education during an emergency: A guide based on the responses to the COVID-19 pandemic. MedEdPublish, 9(1), 1-12. https://doi.org/10.15694/mep.2020.000069.1.

Utami, W. B., Amir, Y. H., Ponoharjo, \& Aulia, F. (2019). Pengembangan Model Manajemen Kurikulum 2013. Quality, 7(2), 114. https://doi.org/10.21043/quality.v7i2.5792.

Wahyono, P., Husamah, H., \& Budi, A. S. (2020). Guru profesional di masa pandemi COVID-19: Review implementasi, tantangan, dan solusi pembelajaran daring. Jurnal Pendidikan Profesi Guru, 1(1), 51-65. http://ejournal.umm.ac.id/index.php/jppg/article/view/12462. 